\title{
10. MAGNETOSTRATIGRAPHIC STUDIES OF CRETACEOUS SEDIMENTS FROM DSDP SITE 369
}

\author{
B.H. Keating' and C.E. Helsley, ${ }^{2}$ Institute for Geosciences, \\ University of Texas at Dallas, Box 688, Richardson, Texas
}

\begin{abstract}
Results from a paleomagnetic study of Cretaceous sediments from Site 369 indicate that the Late Cretaceous is characterized by a long interval of normal polarity ranging in age from latest Campanian to Aptian. Three intervals of reversed polarity were found in sediments of middle Maestrichtian and late Aptian age. Two of these polarity zones have been tentatively correlated with sea floor anomalies 31 (Heirtzler et al., 1968) and M-O (Larson and Hilde, 1975).
\end{abstract}

\section{INTRODUCTION}

The paleomagnetic reversal sequence for the Cenozoic is well known back to Miocene times. However, Mesozoic reversal sequences are poorly known. Thus, an extensive study of the late Mesozoic, especially the Cretaceous period, has been begun and includes paleomagnetic studies of 21 DSDP cores and 15 land sections. The objective of this study is the construction of a continuous Late Cretaceous paleomagnetic reversal sequence, which can be integrated with both radiometric dates and biostratigraphic zonations. DSDP material, particularly the extensively sampled Cretaceous portions of cores from Legs 40 through 44, appears to be ideally suited for portions of this study, for it represents extensive collections of Lower Cretaceous material that can be dated by biostratigraphic means.

\section{SAMPLING PROCEDURE}

Samples were collected from DSDP Leg 41, Site 369 (Figure 1), drilled in the northeastern Atlantic Ocean, on the African continental shelf. For the most part, 2.5$\mathrm{cm}$-diameter cylindrical samples were collected using cylindrical plastic sample holders. In more consolidated portions of the core, 2.5 -cm-diameter cylindrical samples were drilled from the sediment core using a diamond drill bit, and then cut to cylinders $2.5 \mathrm{~cm}$ in length.

Sampling was restricted to core segments whose length was greater than a core diameter, which was done to eliminate inversions of core segments which could have taken place in drilling. An arrow marking the up direction was scribed along the center of the split core face. The core was then taken at right angles to and centered upon the orientation scribe.

\footnotetext{
'Contribution No. 320.

${ }^{2}$ New address effective August 1976, Hawaii Institute of Geophysics, University of Hawaii, 2525 Correa Rd., Honolulu, Hawaii.
}

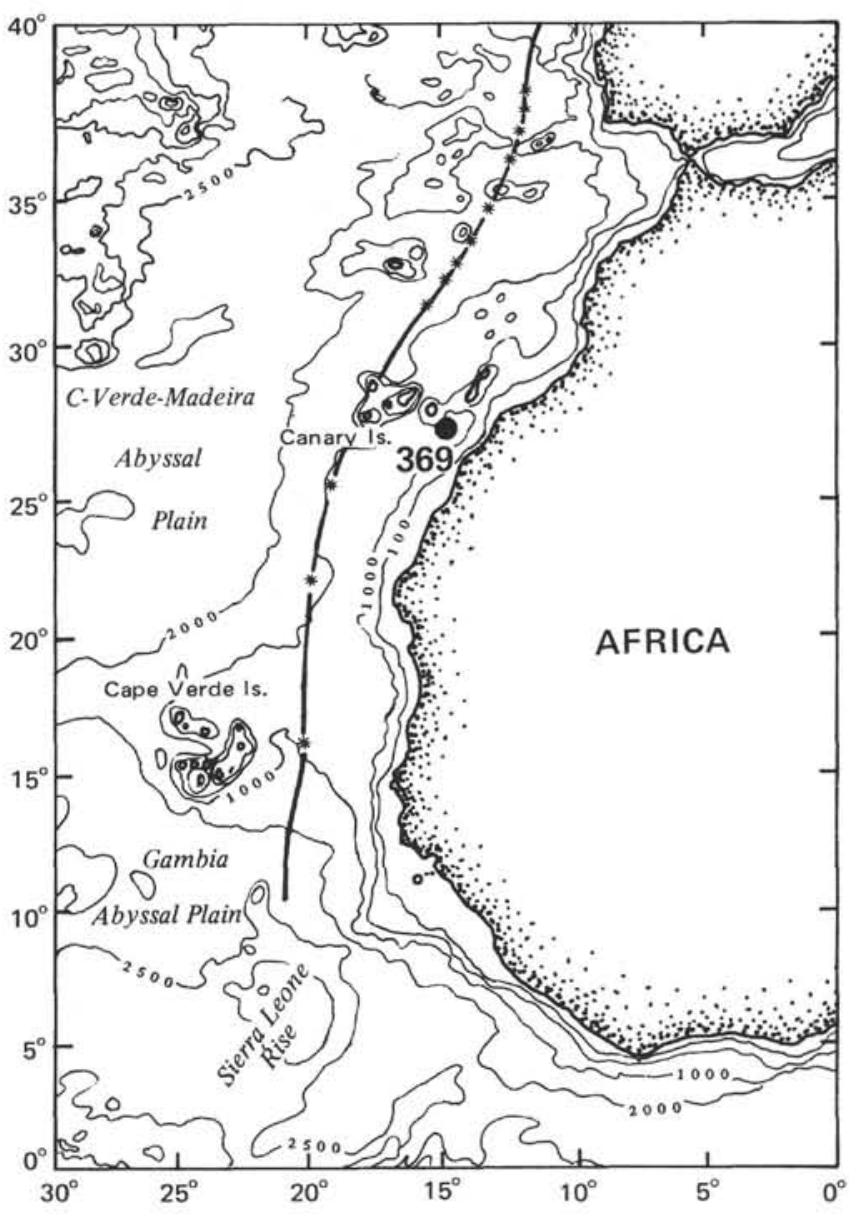

Figure 1. Map of the northeast Atlantic Ocean showing position of DSDP Site 369.

The samples were flown to Dallas and refrigerated in order to minimize the chemical, physical, and magnetic changes that take place during desiccation and oxidation. All samples were measured on a ScT cryogenic magnetometer within a magnetically shielded room. 
Selected samples were demagnetized at 100 -oe peak alternating field (AF).

\section{LITHOSTRATIGRAPHY}

Hole 369 penetrated approximately 100 meters of Cretaceous sediments. These sediments were divided into two lithologic units by the shipboard scientists. The first (Unit 2) consists of argillaceous limestones, marls, and chalk. The lower unit (Unit 3) consists of silty nannofossil marls.

Unit 2 has been divided into Subunits $2 \mathrm{~A}$ (Cores $369 \mathrm{~A}-33$ to $369 \mathrm{~A}-37$ ) and $2 \mathrm{~B}$ (Cores 369A-38 to 369A40). Subunit $2 \mathrm{~A}$ consists of argillaceous nannofossil chalks and limestones. There are thin layers of chert and porcellanite nodules and stringers throughout this unit. The subunit is light gray in color and bioturbated.

Subunit 3 consists of nanno marls and chalks with scattered gypsum crystals. The unit is bioturbated throughout. Pyrite is found disseminated throughout Core 369A-41.

Biostratigraphic studies suggest that the portion of Unit 2 sampled ranges in age from Coniacian to Maestrichtian. Nannofossils and foraminifera were abundant in this unit and Radiolaria are common in Cores 369A-35 to 369A-39. Planktonic foraminifera from Core 369A-36 were assigned to the Globotruncana gansseri Subzone (planktonic foraminifera) which is Maestrichtian in age. Cores 369A-37 and 369A-38 were assigned to the lower Maestrichtian-upper Campanian, while Core 369A-39 was assigned a Campanian age.

Unit 3, an olive-black silty nannofossil marl, contains abundant well preserved planktonic foraminifera. Core 369A-41 was assigned a late Aptian age and Cores $369 \mathrm{~A}-42$ through $369 \mathrm{~A}-44$ are assigned to the uppermost Aptian-lowermost Albian. Biostratigraphic studies of both nannofossils and Radiolaria allow age assignments in agreement with those made utilizing planktonic foraminifera.

Abundant planktonic foraminifera, good preservation, and high planktonic to benthonic foraminiferal ratios suggest that a pelagic, bathyal environment existed throughout the Cretaceous at this site.

\section{PALEOMAGNETIC MEASUREMENTS}

One hundred and eighty-nine samples were collected from Cores 369A-36 through 369A-47 at this site. Recovery at this site was approximately $80 \%$. All samples were measured on a cryogenic magnetometer, and the Natural Remanent Magnetization (NRM), inclinations and intensity are shown in (Figure 2). Selected samples were demagnetized at 100 oe (peak alternating field) and are plotted on the same figure.
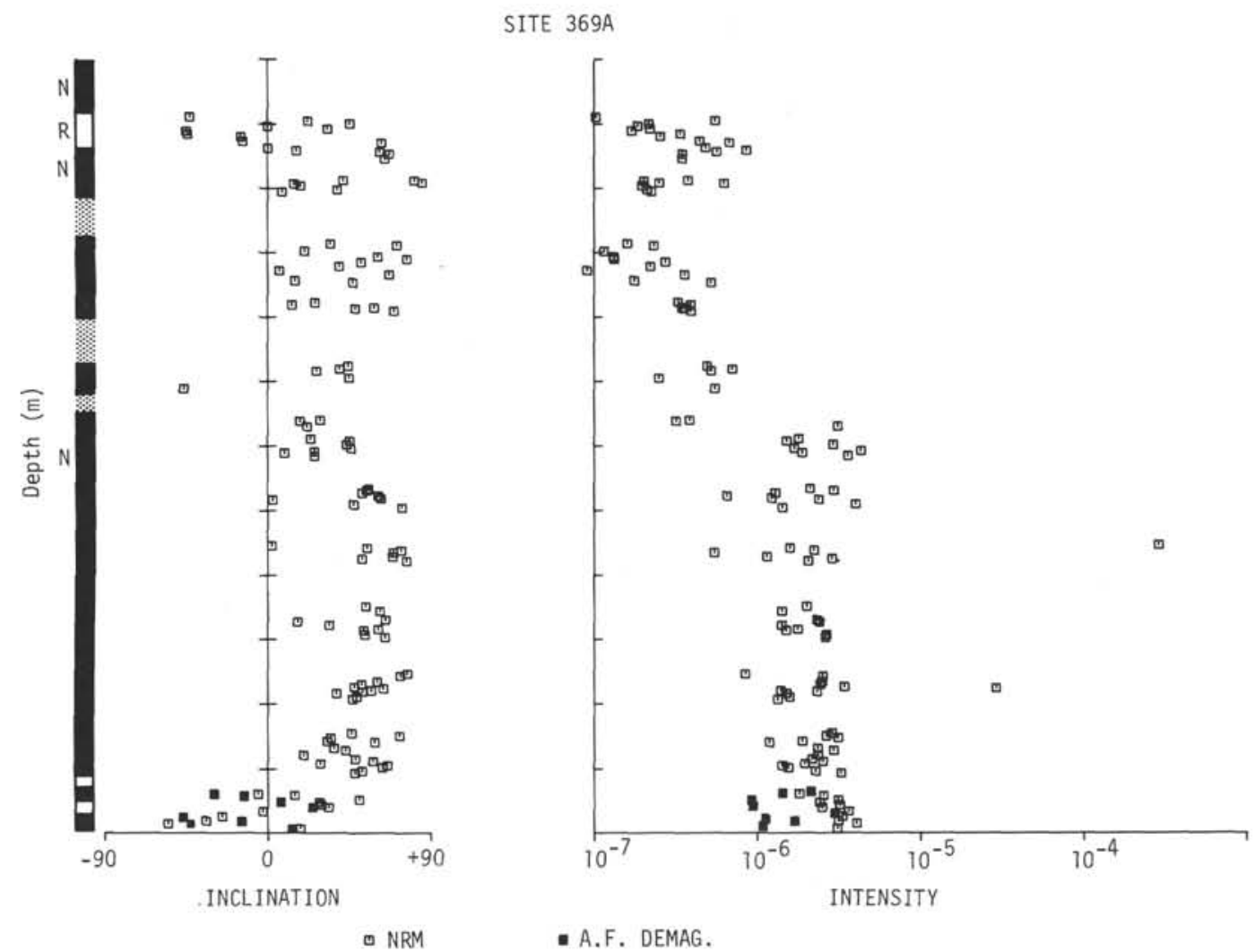

Figure 2. Stratigraphic plot of sample inclinations and intensity for samples from Hole 369. Sample intensity is measured in emu uncorrected for variable sample volume. Open symbols indicate $\mathrm{nrm}$ results. Closed symbols indicate results after demagnetization to 100 oe. Each tic mark on the vertical scale represents 10 meters. The interval studied ranged from 2145.1 to 2555.5 meters depth below the rig fioor. Gaps between data points are due to poor recovery or gaps between adjacent cores resulting from drilling. The gaps are illustrated with the stipple pattern. Black represents normal polarity and white represents reversed polarity in the column at left in the diagram. 
AGE

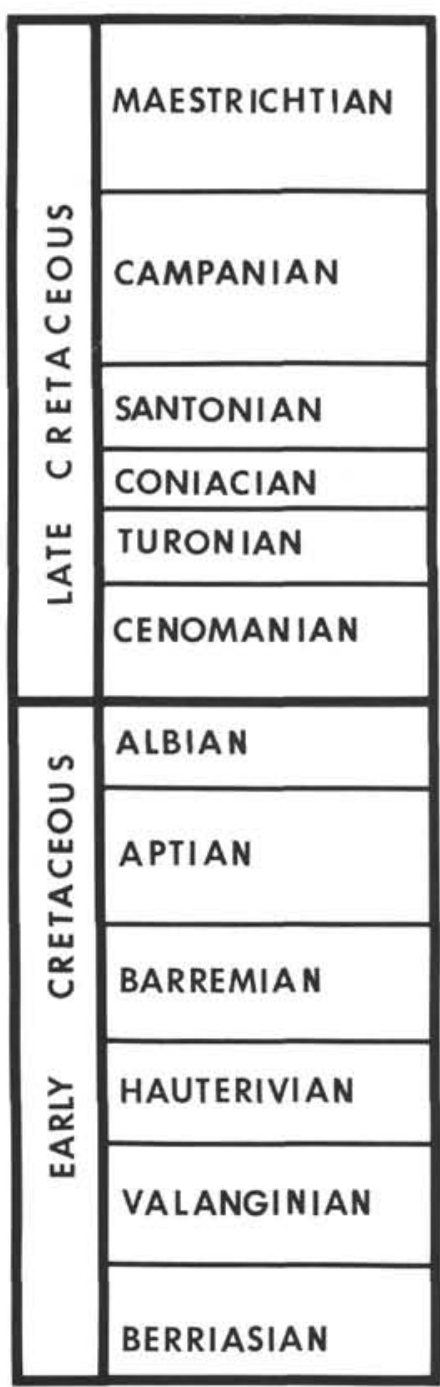

SEAFLOOR

KEATING ET. AL, 1975

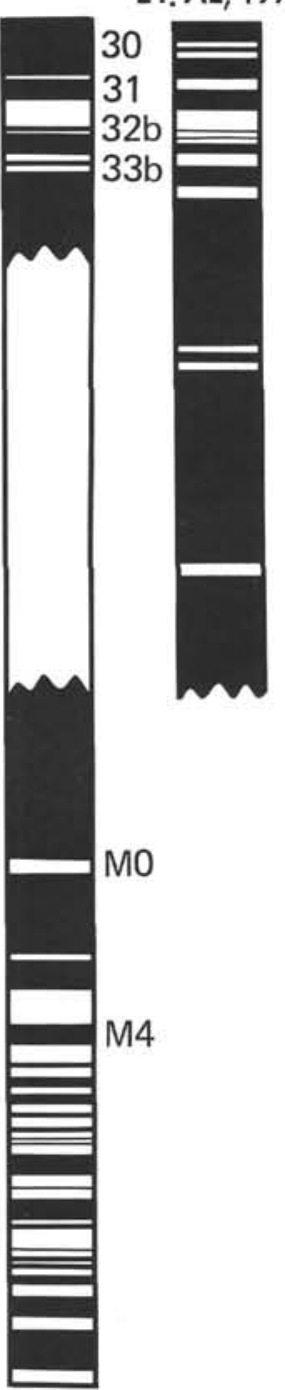

Figure 3. Summary of Cretaceous polarity sequences based upon sea-floor magnetic anomalies and the paleomagnetic study of marine sediments. Summarized from Larson and Hilde, 1975; Sclater and Fisher, 1974; and Keating et al., 1975.

\section{RESULTS}

The NRM results from Site 369 show that only 2 of the 12 cores sampled have mixed polarity. The remaining cores from this site are normally magnetized and correspond to the magnetostratigraphic interval termed the Cretaceous Quiet Zone or Interval (Helsley and Steiner, 1969; Keating et al., 1975). Three intervals of reversed polarity were found. The first, Sections 369A$36-2$ and $369 \mathrm{~A}-36-3$, is Maestrichtian in age and is assigned to the $G$. gansseri Subzone (Pessagno zonation, planktonic foraminifera). By comparing this reversal with the established reversal sequence for the Maestrichtian (Keating et al., 1975) it can be seen that the reversed polarity zone probably corresponds to sea floor anomaly 31 (see Figure 3 ).

Two additional reversed polarity zones, Sections $369 \mathrm{~A}-47-1,369 \mathrm{~A}-47-3$. and 369A-47-4 are assigned a late Aptian age. The observation of reversed polarity intervals in this hole is compatible with the observations made in the study of Cretaceous sediments from Leg 40 . However, it is not consistent with the polarity sequence presented by Larson and Hilde (1975) and again suggests that there are more anomalies present in the sedimentary record than have been identified through the study of sea-floor magnetic anomalies.

The reversed interval found in Sections 369A-47-3 and $369 \mathrm{~A}-47-4$ is relatively long in comparison to others found of this age (Keating and Helsley, in press). This reversed interval could then possibly correspond to sea floor anomaly $\mathrm{M}-\mathrm{O}$, the first anomaly of the Msequence of relatively long duration (see Figure 3).

The remaining reversal then would postdate the Msequence (Larson and Hilde, 1975). Such a suggestion, however, is more in the line of speculation than a conclusion. The suggestion is made merely on relative stratigraphic thickness, which could as easily be explained by local variations in sedimentation rate.

A major break in the intensity of magnetization (shown in Figure 2) occurs at approximately 2187 meters below rig floor and can be directly related to a change in the lithology. The change in intensity corresponds to the change from bluish white-greenish gray argillaceous nannochalk to black argillaceous marl with interbedded olive-gray nannofossil marl. Pyrite is present but rare in the upper portion of the core, which is characterized by low intensity. The lower portion of the core, whose intensity is stronger by approximately an order of magnitude is characterized by an absence of pyrite and presence of common micronodules.

The significance of the paleomagnetic results from this site is that despite sedimentary hiatuses the nature of the Cretaceous Quiet Zone or Interval is clearly illustrated. Once again a reversed polarity interval of late Aptian age has been identified suggesting the need for revision of the Larson and Hilde (1975) reversal sequence for the Early Cretaceous.

\section{ACKNOWLEDGMENTS}

John Fiske helped collect these samples at Lamont. In addition, we thank Barry Lienert for aid with programs and equipment and Jane Neugent. This work was supported by the National Science Foundation under Grant GA43299.

\section{REFERENCES}

Heirtzler, J.R., Dickson, G.S., Herron, E.M., Pitman, W.C., and LePichon, X., 1968. Marine magnetic anomalies, geomagnetic field reversals, and models of the ocean floor and continents: J. Geophys. Res., v. 73, p. 2119.

Helsley, C.E. and Steiner, M.B., 1969. Evidence for long intervals of normal polarity during the Cretaceous period: Earth Planet. Sci. Lett., v. 5, p. 325.

Keating, B.H. and Helsley, C.E., in press. Magnetostratigraphy of Cretaceous age sediments from Sites 361, 363, 364, and 365. In Bolli, H.M., Ryan, W.B.F., et al., Initial Reports of the Deep Sea Drilling Project, Volume 40: Washington (U.S. Government Printing Office).

Keating, B.H., Helsley, C.E., and Pessagno, E.A., Jr., 1975. Late Cretaceous reversal sequence: Geology, v. 2, p. 75.

Larson, R.L. and Hilde, T.W.C., 1975. A revised time scale of magnetic reversals for the Early Cretaceous and Late Jurassic: J. Geophys. Res., v. 80, p. 2586. 
B.H. KEATING, C.E. HELSLEY

Sclater, J.G. and Fisher, R.L., 1974. Evolution of the East Central Indian Ocean, with emphasis on the tectonic setting of the Ninetyeast Ridge: Geol. Soc. Am. Bull., v. 85, p. 683 . 